Volume 2, Issue 3, December 2020

Journal Homepage: http://pusdikra-publishing.com/index.php/jetl

\title{
Fungsi Kaderisasi Dalam Meningkatan Kualitas Kepemimpinan
}

Muhammad Rizki Syahputra1, T. Darmansah²

Universitas Islam Negeri Sumatera Utara

Universitas Islam Negeri Sumatera Utara

\begin{tabular}{|c|c|}
\hline & ABSTRACT \\
\hline $\begin{array}{l}\text { ARTICLE INFO } \\
\text { Article history: } \\
\text { Received } \\
\text { 16 Oktober } 2020 \\
\text { Revised } \\
26 \text { Oktober } 2020 \\
\text { Accepted } \\
19 \text { November } 2020\end{array}$ & $\begin{array}{l}\text { The purpose of this study was to determine the function of regeneration } \\
\text { in improving leadership quality. In this study, using the library research } \\
\text { method (library research) by collecting a number of books, magazines, } \\
\text { journals, lifet relating to the problem and research objectives. Collecting } \\
\text { data with the results of previous research which support data on research } \\
\text { themes related to leadership regeneration and leadership quality with the } \\
\text { research process starting with the stages of identifying, finding relevant } \\
\text { information, analyzing the findings, and then developing and expressing } \\
\text { them into new findings related to the regeneration function in improving } \\
\text { leadership qualities. The results of this study found that, 1) Informal } \\
\text { cadre, 2) formal cadre. A good leader is not seen by how many followers } \\
\text { he has, and how long he leads, but by how much he can create new } \\
\text { leaders. Leadership refers to a process to move a group of people towards } \\
\text { a predetermined goal by encouraging them to act in a non-coercive } \\
\text { manner. Thus, it can be said that leadership is a role and also a process for } \\
\text { influencing others. Whereas a leader is a member of an association who is } \\
\text { given a certain position and is expected to act according to his position. A } \\
\text { leader is someone in an association who is expected to be able to use his } \\
\text { influence in realizing and achieving group goals accompanied by full } \\
\text { honesty. An honest leader is someone who leads and not someone who } \\
\text { uses his position to lead. }\end{array}$ \\
\hline Kata Kunci & Regeneration, quality, leadership \\
\hline How to cite & $\begin{array}{l}\text { Muhammad Rizki Syahputra1, T. Darmansah². (2020). Fungsi } \\
\text { Kaderisasi Dalam Meningkatan Kualitas Kepemimpinan. Jurnal Journal of } \\
\text { Education and Teaching Learning (JETL). }\end{array}$ \\
\hline
\end{tabular}

\section{PENDAHULUAN}

Kehidupan organisasi modern berciri dominan yang berpengaruh ialah adanya kondisi yang menunjukkan pertentangan atau saling berlawanan antara hal-hal seperti: tuntutan organisasi dengan keinginan masing-masing anggota organisasi, pekembangan ilmu dan teknologi yang canggih dengan system social tradisional, stabilitas dengan inovasi, keseragaman dengan perubahan, persesuaian dengan kreativitas, perkembangan dinamika organisasi dengan birokrasi yang sempit, dan sebagainya. Poses tersebut akan terus terjadi dan tidak pernah berhenti. Persoalan yang muncul adalah bagaimana pemimpin suatu organisasi itu dapat mengatasi dan menyelaraskan segala macam kontradiksi tersebut untuk mendukung tercapainya tujuan suatu organisasi. Oleh sebab itu, diperlukan adanya pemimpin yang efektif dan berkualitas, yaitu seorang pemimpin yang mampu menghadapi dan mengikuti 
perkembangan ilmu pengetahuan dan teknologi, serta gerak masyarakat yang selalu berkembang dan terkadang perkembangannya sangat cepat.

Sikap fleksibelitas pemimpin yang tercermin pada tiga unsur pokok perlu dimiliki yaitu cocok, sejalan dan taat asaa. seorang pemimpin selalu mengatur dan mengendalikan perilakunya sesuai dengan situasi dimana proses kepemimpinan itu dilaksanakan. Sejalan dalam arti mengarahkan perilaku kepemimpinannya sesuai dengan tugas dan kenyataan organisasi yang dipimpinnya. Sedangkan taat asas yaitu ketaatan atau sikap konsisten pemimpin pada kepribadian dan keyakinannnya. Atas dasar ketiga hal tersebut, kepemimpinan sebagai suatu proses dan merupakan suatu interaksi antara sesama manusia yang berorientasikan pada tindakan. Kualiats kepemimpinan baru dapat dicapai apabila dalam diri setiap pemimpin tumbuh kesadaran dan pemahaman yang mendalam terhadap makna kepemimpinan dengan segalaaspeknya.

Untuk mendapatkan pemimpin yang baik dimasa sekarang dan yang akan dating perlu adanya kaderisasi kepemimpinan yang berkualitas sehingga dapat menghasilkan pemimpin-pemimpin yang mampu mempertanggungjawabkan apa yang dipimpinnya, dan mampu membawa Negara menjadi Negara yang maju dan madani yaitu Negara yang terhindar dari korupsi, kolusi, dan nepotisme.

\section{METODE PENELITIAN}

Penelitian ini menggunakan metode studi pustaka (library reseach) dengan mengumpulkan sejumlah buku-buku, majalah, jurnal, lifet yang berkenaan dengan masalah dan tujuan penelitian. (Danial A.R. 2009:80) Pengumpulan data dengan hasil penelitian terdahulu yang menjadi pendukung data pada tema penelitian terkait kaderisasi kepemimpinan dan kualitas kepemimpinan dengan proses penelitian dimulai dengan tahapan mengidentifikasi, menemukan informasi yang relevan, menganalisis hasil temuan, dan kemudian mengembangkan dan mengekspresikannya menjadi temuan baru berkaitan dengan fungsi kaderisasi dalam miningkatkan kualitas kepemimpinan.

\section{HASIL DAN PEMBAHASAN}

\section{Kaderisasi Kepemimpinan}

Menurut Robbins \& Judge dalam Wibowo (2014:264) Kepemimpinan adalah kemampuan mempengaruhi suatu kelompok menuju pencapaian sebuah visi atau serangkaian tujuan. Selanjutnya Menurut Swasta dalam Ambarita, dkk (2016:42) kepemimpinan adalah prilaku atau kemampuan yang dimiliki seorang dalam memotivasi orang lain untuk bekerja ke arah pencapaian tujuan tertentu dalam sebuah organisasi. Dengan demikian kepemimpinan sebagai proses dimana seseorang individu mempengaruhi orang lain untuk mencapai tujuan bersama. 
Lebih lanjut, Syahputra dan Suheiri (2017:271) Kepemimpinan merupakan salah satu faktor utama dalam kehidupan berorganisasi yang memegang peranan penting. Karena peran pemimpin sebagai pengatur dalam proses kerjasama antara pemimpin dengan individu maupun pemimpin dengan kelompoknya. Ada beberapa faktor-faktor yang mempengaruhi kepemimpinan transformasional, yaitu perilaku yang ideal, motivasi inspiratif, stimulasi intelektual, dan konsiderasi yang diindividualisasikan.

Fadhli (2018:118) Kepemimpinan merupakan tema yang penting dan selalu mendapatkan perhatian saat ini. Kepemimpinan menjadi subyek dari banyak perdebatan ilmiah, seminar dan berbagai kajian lainnya baik di dalam maupun luar negeri. Memiliki pemimpin yang berkualitas, kompeten dan efektif adalah penting untuk dapat memberikan kesejahteraan anggota organisasi dan stakeholder lainnya.

Partanto, (1994:29) Kader dalam kamus ilmiah popular adalah orang yang didik untuk menjadi pelanjut tongkat estapet suatu partai atau organisasi: tunas muda. Dan dalam kamus induk istilah imliah seri intelektual disebut bahwa kader adalah generasi penerus atau pewaris dimasa depan dalam organisasi, pemerintah atau partai politik. (Albarry, 2003:349)

Mangkubumi (1989:59) kaderisasi sebagai suatu siklus yang berputar terus dengan gradasi yang meningkat dan dapat dibedakan menjadi tiga komponen utama, yaitu: Pendidikan kader: disampaikan berbagai pengetahuan yang dibutuhkan. Penugasan kader: mereka diberi kesempatan untuk melibatkan diri dalam kegiatan-kegiatan organisasi sebagai latihan pematangan dan pendewasaan. Pengerahan karir kader: diberi tanggung jawab lebih besar dalam berbagai aspek petjuangan sesuai potensi dan kemampuan yang ada.

Pemimpin yang baik bukan di lihat dari seberapa banyak pengikutnya, dan seberapa lama ia memimpin, tapi terlihat dari seberapa banyak ia bisa menciptakan pemimpin-pemimpin baru. Kepemimpinan mengacu pada suatu proses untuk menggerakkan sekumpulan manusia menuju ke suatu tujuan yang telah ditetapkan dengan mendorong mereka bertindak dengan cara tidak memaksa. Dengan demikian, dapat dikatakan bahwa kepemimpinan adalah suatu peranan dan juga merupakan suatu proses untuk memengaruhi orang lain. Sedangkan pemimpin adalah anggota dari suatu perkumpulan yang diberi kedudukan tertentu dan diharapkan dapat bertindak sesuai dengan kedudukannya. Seorang pemimpin adalah seseorang dalam suatu perkumpulan yang diharapkan mampumenggunakan pengaruhnya dalam mewujudkan dan mencapai tujuan kelompok yang disertai dengan penuh kejujuran. Pemimpin yang jujur ialah seorang yang memimpin dan bukan seorang yang menggunakan kedudukan untuk memimpin.

Menurut Veithzal dan Mulyadi (2011:95) Kepemimpinan juga bukan sekedar proses penurunan sifat / bakat dari orangtua kepada anaknya, tetapi lebih ditentukan oleh semua aspek-aspek kepribadian, sehingga dapat menjalankan kepemimpinan yang efektif, diantaranya adalah: a) inteligensi yang cukup tinggi, b) Kemampuan melakukan analisis situasi dalam 
mengambil keputusan, c) Kemampuan mengaplikasikan hubungan manusiawi yang efektif agar keputusan dapat dikomunikasikan.

Partanto dan Dahlan (1994:293) Pengkaderan adalah orang yang didik untuk menjadi pelanjut tongkat estafet suatu partai atau organisasi, calon tunas muda, generasi muda. Menurut Veithzal dan Mulyadi (2011:96) Kader diartikan sebagai orang yang diharapkan akan memegang jabatan atau pekerjaan penting di pemerintahan, partai, dan lain-lain. Sedangkan pengkaderan adalah proses, cara, perbuatan mendidik atau membentuk seseorang menjadi kader. Kaderisasi kepemimpinan berarti proses mempersiapkan seseorang untuk menjadi pemimpin pengganti dimasa depan,yang akan memikul tanggungjawab penting dilingkungan suatu organisasi.

Selanjutnya, Kaderisasi diperlukan, Karena semua manusia termasuk yang sekarang menjadi pemimpin, suatu saat pasti akan mengakhiri kepemimpinannya, baik dikehendaki maupun tidak. Proses tersebut dapat terjadi karena; a) Dalam suatu organisasi ada ketentuan periode kepemimpinan seseorang, b) Adanya penolakan dari anggota kelompok, yang menghendaki pemimpinnya diganti, baik secara wajar maupun tidak wajar, c) Proses alamiah,menjadi tua dan kehilangan kemampuan memimpin, d) Kematian. Lebih lanjut Veithzal dan Mulyadi (2011:96) Kaderisasi perlu diupayakan karena: a) Agar tersedia jumlah pemimpin yang cukup dan berkualitas sehingga kader aktif mempersiapkan diri agar lebih berkualitas dari generasi sebelumnya, b) Organisasi membuat perkiraan dalam jumlah, jenis dan kualitas pemimpin yang diperlukan di masa depan secara berkesinambungan. Menurut

Lebih lanjut Nawawi, (1993:188) Pengkaderan juga diartikan sebagai proses perbuatan mendidik atau membentuk seseorang menjadi kader. Fatah, (2000:54) Kader pada mulanya adalah suatu istilah militer atau perjuangan yang berasal dari kata carde yang definisinya adalah pembinaan yang tetap sebuah pasukan inti (yang terpercaya) yang sewaktu waktu diperlukan.

Menurut Veithzal dan Mulyadi (2011:96) ada beberapa bentuk keterbatasan kepemimpinan dalam melaksanakan kepemimpinannya, yaitu: Keterbatasan Manusiawi, Manusia yang berhasil memperoleh kesempatan sebagai pemimpin tidak dapat lepas dari kelemahan yang bersifat universal dan kodrati. Kelemahan-kelemahan itu mengakibatkan keterbatasan dalam merealisasikan kepemimpinannya,

1) Keterbatasan Norma Spiritual

Harkat kemanusiaan yang tinggi merupakan pembatas perilaku setiap manusia, termasuk dalam melaksanakan fungsi kepemimpinannya. Harkat manusia memikul tanggung jawab dalam arti tingkah laku dibatasi oleh nilai-nilai tertentu di antaranya norma sosial dan norma sipritual/ agama atau kepercayaan yang dipeluk oleh seorang pemimpin. Keterbatasan norma spiritual yaitu keterbatasan karena manusia sebagai pemimpin memiliki kewajiban dan sekaligus melekat pada dirinya berupa larangan yang harus dipatuhi.

2) Keterbatasan Fisik/ Jasmaniah 
Keterbatasan kepemimpinan karena unsur fisik/ jasmaniah antara lain meliputi: a) Usia, Sebagai pemimpin pada usia muda, setiap orang memilki energi (tenaga) fisik yang bersifat maksimal untuk berprestasi, untuk mewujudkan kreativitas dan inisiatif yang positif dibandingkan dengan pemimpin yang sudah lanjut usianya, b) Fisik yang sehat, Fisik manusia dapat letih dan sakit untuk itu perlu istirahat serta tidur yang cukup, memerlukan makanan yang bersih dan bergizi dengan maksud mewujudkan kepemimpinan yang efektif.

3) Fisik yang bervariasi/ jenis kelamin

Pengaruh jenis kelamin hanya dipengaruhi oleh norma-norma sosial dan agama

Menurut Veithzal dan Mulyadi (2011:96) Dalam pelaksanaannya kaderisasi terdiri dari dua macam yaitu :

1. Kaderisasi Informal

Kaderisasi disebut juga proses pendidikan termasuk proses belajar di sekolah, peluang yang diberikan orang tua (pendidikan keluarga), peluang dalam kurikulum dan program ektra kurikuler serta lingkungan. Dalam kaderisasi informal terdapat beberapa indicator atau kriteria kelebihan calon pemimpin yang berkepribadian positif dalam merebut kepemimpinan yang dilakukannya secara gigih berdasarkan prestasi, loyalitas dan dedikasi pada kelompok/organisasi, memiliki sifat dan sikap pasrah kepada Tuhan yang Maha Esa sebagaipenentu yang mutlak. Oleh karena itu, generasi terdahulu dan generasi muda yang sedang berada dalam proses kaderisasi, harus samasama aktif mengerjakan segala sesuatu yang baik dan bermanfaat guna menghasilkan calon-calon pemimpin yang berkualitas. Sebaliknya harus aktif pula menghindari atau tidak mengerjakan segala sesuatu yang akan berakibat dihasilkannya calon-calon pemimpin yang buruk kualitasnya. Dengan demikian, setiap generasi yang terdahulu, terutama yang banyak berkomunikasi dengan generasi muda atau yang menduduki posisi kepemimpinan yang penting, selalu harus memberikan contoh dan keteladanan, bimbingan dan pengarahan agar generasi muda menyerap secara sengaja atau tidak sengaja sesuatu yang baik, untuk mempersiapkan dirinya menjadi pemimpin dengan memperlihatkan sikap dan akhlak yang baik. Dengan demikian,perilaku yang menggambarkan akhlak atau kepribadian pemimpin dalam menjalankan kepemimpinannya dan bagaimana cara hidupnya, ternyata sangat besar pengaruhnya bagi proses kaderisasi informal.

2. Kaderisasi Formal

Perkataan formal menunjukkan bahwa usaha mempersiapkan seseorang sebagai calon pemimpin dilakukan secara berencana, teratur dan tertib, sistematis, terarah dan disengaja. Usaha itu bahkan dapat diselenggarakan secara melembaga, sehingga semakin jelas sifat formalnya. Untuk itu proses kaderisasi mengikuti suatu kurikulum yang harus dilaksanakan selama jangka waktu tertentu dan berisi bahan-bahan teoritis dan praktik tentang kepemimpinan serta bahan-bahan lain sebagai pendukungnya. 
Menurut Veithzal dan Mulyadi (2011:98) Usaha kaderisasi intern yang bersifat formal,dapat ditempuh dengan beberapa cara sebagai berikut:

a. Memberi kesempatan menduduki jabatan pemimpin pembantu, Kaderisasi ini dilakukan dengan cara mengangkat atau memberikan kesemmpatan secara formal pada seorang calon pemimpin yang berusia muda, untuk memangku jabatan pimpinan.

b. Latihan kepemimpinan didalam atau diluar organisasi, Latihan kepemimpinan yang dimaksud adalah memberikan kesempatan kepada anggota organisasi untuk mengikuti suatu program mempersiapkan calon pemimpin.

c. Memberikan tugas belajar, Untuk mempersiapkan calon pemimpin yang berkualitas dalam suatu organisasi, perlu dilakukan kegiatan kaderisasi denganmemberikan tugas belajar pada lembaga pendidikan yang jenjangnya lebih tinggi,bagi anggotanya yangpotensial, diharapkan seorang kader akan meningkatkan pengetahuan, wawasan, dan keterampilannya dalam memimpin.

d. Penugasan sebagai pucuk pimpinan suatu unit, Kaderisasi dapat dilakukan dengan cara menugaskan seorang anggota menjadi pucuk pimpinan pada salah satu cabang atau perwakilannya di daerah.

Kaderisasi kepemimpinan secara formal dan bersifat ekstern dapat dilakukan sebagai berikut:

a. Menyeleksi sejumlah generasi muda lulusan lembaga pendidikan jenis dan jenjang tertentu, untuk diangkat sebagai pemimpin suatu unit yang sesuai atau ditugaskan magang sebelum memimpin unit tersebut.

b. Menyeleksi sejumlah organisasi lulusan lembaga pendidikan jenis dan jenjang tertentu, kemudian ditugaskan belajar pada lembaga pendidkan yang lebih tinggi, didalam atau diluar negeri. Tugas belajar itu dilakukan dengan memberikan ikatan dinas atau beasiswa atau diberi status pegawai atau karyawan yang mendapat penghasilan, meskipun tidak di pekerjakan.

c. Memesan sejumlah generasi muda dari lembaga pendidikan formal dengan program khususs atau spesialisasi, sesuai dengan bidang yang dikelola organisasi pemesan. Pemesan mendapatkan syarat-syarat tertentu, misalnya syarat nilai diatas rata-rata dan sebagainya. Generasi muda yang telah tamat dan memenuhi persyaratan pada jalur yang kelak akan memberi peluang menjadi pimpinan unit.

d. Menerima sejumlah generasi muda dari suatu lembaga pendidikan untuk melakukan kerja praktik dilingkungan organisasi. Dari pengamatan bila ditemukan generasi muda yang dinilai memenuhi persyaratan untuk dikaderkan mennjadi pemimpin, dapat ditawari pekerjaan setelah tamat.

Cara agar kaderisasi kepemimpinan itu berjalan seperti yang kita harapkan adalah sebagai berikut,

1) Beri Kepercayaan 
Beri kepercayaan kepada staf atau bawahan Anda, biarkan mereka melakukan apa yang mereka anggap benar, namun arahan strategis/konsep yang matang telah Anda berikan. Setelah itu lakukan evaluasi terkait kerja yang telah dia kerjakan tetapi, sifatnya bukan menggurui, namun pembahasan bersama menuju arah yang terbaik bagi perusahaan.

2) Beri Semangat dan Motivasi

Motivasi merupakan hal yang sangat penting dalam organisasi Apabila terdapat beberapa hal yang tidak sejalan dengan pakem-pakem yang telah ditetapkan, berilah feedback (umpan balik / evaluasi) kepada staff Anda tersebut. Jangan pernah marah-marah, apalagi memaki staff tersebut, karena hal itu akan membuat dia trauma dan bernyali kecil, dampak negatifnya adalah dia jadi takut untuk mengambil keputusan, karena khawatir dengan resiko yang akan dihadapi.

3) Menjalin Kedekatan.

Jalinlah kedekatan dengan staf Anda, secara terbuka dan rileks membahas situasi perusahaan dari beberapa aspek (organisasi, pemasaran, operasional, keuangan, dll), sesekali mintai pendapatnya. Anda pun menjabarkan konsep-konsep pemikiran Anda dalam membangun sebuah Organisasi.

\section{Peningkatan Kualitas Kepemimpinan}

Peningkatan kualitas kepemimpinan berarti suatu upaya untuk meningkatkan kemampuan, kualifikasi dan kompetensi seseorang dalam memimpin suatu organisasi atau yang lainnya. Menurut Veithzal dan Mulyadi (2011:104) Usaha-usaha yang perlu dilakukan dalam meningkatkan kualitas kepemimpinan sebagai berikut:

1. Berfikir efektif dalam menetapkan keputusan, Berfikir efektif dalam menetapkan keputusan. Berfikir merupakan potensi psikis yang sangat istimewa,yang diberikan oleh Tuhan Yang Maha Esa. Dalam sejarah berfikir manusia ternyata dengan kemampuannya itu, manusia telah berusaha memikirkan segala sesuatu, termasuk juga berfikir mengenai proses berfikir itu sendiri. Selanjutnya, Proses berfikir yang berlangsung didalamdiri seseorang dapat dibedakan menjadi: a) Berfikir yang bersifat intra-personal yakni yang berlangsung didalam psikis atau otak seseorang, yang bersangkutan dengan atau untuk dirinya sendiri, b) Berfikir bersifat inter-personal, yakni yang berlangsung didalam psikis atau otak seseorang,yang berhubungan dengan dan berakibat sesuatu pada orang.

2. Mengomunikasikan hasil berfikir

Terdapat beberapa factor yang memengaruhi dalam mengomunikasikan hasil berfikir baik lisan maupun tertulis yaitu: a) Hasil berfikir yang dikomunikasikan sebaiknya yang telah melalui proses berfikir rasional, kritis, dan objektif, dalam arti diyakini benar sebagai sesuatu yang telah diolah secara maksimal, b) Pimpinan harus mengetahui secara tepat tujuan pembicaraan atau tulisan yang akan dikomunikasikannya, agar 
dapat mengetahui manfaat atau keberhasilannya, apabila pesan yang telah disampaikan itu diwujudkan menjadi kegiatan, c) Pemimpin harus berusaha menguasai secara baik, tentang bahan atau pesan, dan masalah yang akan dibicarakan atau disampaikannya secara tertulis.

3. Meningkatkan partisipasi dalam memecahkan masalah Menurut Veithzal dan Mulyadi (2011:108) Kemampuan mewujudkan danmebina kerjasama pada dasarnya berarti mampu mendorong dan memanfaatkan partisipasi anggota organisasi secara efektif dan efisien. Partisipasi dapat dilakukan dalam berbagai kegiatan, yang dapat disebutkan sebagai partisipasi dalam memcahkan masalah itu, akan bermuara pada perkembangan rasa tanggungjawab dalam melaksanakan setiap tugas secara operasional.

4. Menggali dan meningkatkan kreativitas

Kreatifitas berasal dari kata kreatif, yang artinya memiliki daya cipta, memiliki kemampuan untuk mencipta, bersifat daya cipta, pekerjaan yang kreatif menghendaki kecerdasan dan imajinasi. Selanjutanya perkataan kreativitas, diartikan sebagai kemampuan untuk mencipta, daya cipta, prihal berkreasi. Untuk memotivasi, pemimpin dapat menempuh dengan langkah-lngkah sebagai berikut: a) Menciptakan dan mengembangkan suasana atau iklim organisasi yang meransang kreativitas, b) Menciptakan dan mengembangkan kerjasama yang dapat menumbuhkan perasaan ikut bertanggung jawab dalam mewujudkan usaha mengembangkan dan memajukan organisasi, c) Merumuskan tujuan yang menyentuh kepentingan bersama, diiringi dengan usaha memasyarakatnya dilingkungan anggota organisasi. Adapun penyebab utama yang harus diatasi oleh pemimpin yang dapat berakibat anggota organisasi tidak kreatif dan inovatif,yaitu: 1) Suasana atau kondisi organisasi, 2) Kepribadian anggota organisasi, 3) Tekanan rekan sejawat, 4) Sikap pimpinan pada jenjang bawah, 5) Kurang dorongan dan pelatihan.

\section{KESIMPULAN}

Untuk mendapatkan kepemimpinan yang baik dan berkualitas dimasa sekarang dan yang akan datang perlu adanya kaderisasi kepemimpinan, sehingga dapat menghasilkan pemimpin-pemimpin yang mampu bertanggung jawab terhadap apa yang dipimpinnya dan mampu membawa Negara kita menjadi Negara yang terhindar dari korupsi, kolusi dan nepotisme. Kaderisasi kepemimpinan adalah proses mempersiapkan seseorang untuk menjadi pemimpin dimasa depan, yang akan memikul tanggung jawab penting dilingkungan suatu Negara, lingkungan bangsa, lingkungan masyarakat, lingkungan bisnis yang terdiri dari kaderisasi informal dan formal. Hak asasi padadasarnya adalah kebebasan individu dalam mengaktualisasikan diri sebagai manusia yang terdiri dari harkat manusia sebagai makhluk individu, harkat manusia sebagai makhluk social dan sebagai makhluk Tuhan Yang 
Maha Esa. Pemimpin yang berkualitas adalah pemimpin yang dilandasi dengan ketakwaan, jujur, menegakkan kebenaran, keberanian, tanggung jawab, dan keluhuran, kekuatan psikologis serta keikhlasan, kesabaran, dan ketabahan.

\section{DAFTAR PUSTAKA}

Al-Barry, M. Dahlan, L. LyaSofyan Yacob, (2003). Kamus Induk Istilah Ilmiah; Seri Intelektual, Target Press, Surabaya.

Ambarita, B. Dan Nasrun. (2016). Manajemen Pendidikan dan Peningkatan Mutu. Bandung: Alfabeta.

Danial A.R., Endang dan Wasriah, Nana (2009). Metode Penulisan Karya Ilmiah, Bandung: Labiratorium PKn UPI. DPD Golkar DIY.

Fadhli, M. (2018), Internalisasi Nilai-Nilai Kepemimpinan Profetik dalam Lembaga Pendidikan Islam, At-Ta'dib: Jurnal Ilmiah Pendidikan Agama Islam Vol. 10, No. 2, Desember.

Fattah, Nanang, (2000). Landasan Manajemen Pendidikan, Bandung: PT. Remaja Rosada Karya.

Hadari, Nawawi, (1993). Kepemimpinan Memurut Islam, Yogyakarta: Gajah Mada University Press.

Mangkubumi. (1989). Kaderisasi dalam organisasi massa dan politik. Makalah

Partanto, Pius A, M.Dahlan Al-Barry, (1994). Kamus Ilmiah Populer, Arkola. Surabaya.

Syahputra, M.R, dan Suheri. (2017), Hubungan Antara Kepemimpinan Transformasional Dengan Komitmen Kerja Guru di Man 3 Medan, TADBIR - Jurnal Alumni Manajemen Pendidikan Islam, Vol. 03 No. 02 JuliDesember.

Veithzal, R, dan Mulyadi, D. (2011). Kepemimpinan dan Prilaku Organisasi. Jakarta:PT.Raja Gravindo persada.

Wibowo. (2014). Perilaku dalam Organisasi. Jakarta:PT.Raja Gravindo persada. 